\title{
Nutritional components, phytochemicals and biological activities of Sibjeondaebohwan produced from balloon flower by high-temperature aging
}

\author{
Su Cheol Kim ${ }^{1}$, Chae Youn $\mathrm{Im}^{1}$, Chung Eun Hwang ${ }^{1}$, Sang Won Park ${ }^{2}$, \\ Dong-Hee Lee ${ }^{4}$, Kye Man Cho ${ }^{1,5 *}$ \\ ${ }^{1}$ Department of Food Science, Gyeongnam National University of Science and Technology, Jinju 52725, Korea \\ ${ }^{2}$ Department of Pharmacology, School of Medicine, Institute of Health Sciences, Gyeongsang National University, \\ JJinju 52727, Korea \\ ${ }^{3}$ Jayeonejeyag Co., Sancheong 52214, Korea \\ ${ }^{4}$ Industry Academy Cooperation Foundation, Andong National University, Andong 36729, Korea \\ ${ }^{5}$ Herbal Medicine Resources Research, Korea Institute of Oriental Medicine, Naju 58245, Korea
}

\section{고온숙성법에 의해 제조된 도라지 함유 십전대보환의 영양성분, phytochemicals 및 생리활성}

\author{
김수철 ${ }^{1}$ - 임채연 ${ }^{1}$ - 황정은 ${ }^{1}$ - 박상원 ${ }^{2}$ - 강민철 ${ }^{3}$ - 이동희 ${ }^{4}$ - 조계 만 ${ }^{1,5 *}$ \\ ${ }^{1}$ 경남과학기술대학교 식품과학부, ${ }^{2}$ 경상대학교 약리학교실 · 건강과학연구원, ${ }^{3}$ (주)자연애제약, \\ ${ }^{4}$ 안동대학교 산학협력단, ${ }^{5}$ 한국한의학연구원 한약자원연구센터
}

\begin{abstract}
In this study, general Sibjeondaebohwan (G-SDH) and high-temperature aged Sibjeondaebohwan (HTA-SDH) samples were prepared using ten herbal medicinal plants including balloon flower. The nutritional components (five nutrients, fatty acids, and free amino acids), phytochemicals (phenolic acids and flavonols), radical scavenging activities (DPPH, ABTS, and hydroxyl), digestive enzyme inhibitory activities (a-glucosidase and pancreatic lipase), and immune system activation of G-SDH and HTA-SDH were analyzed and compared. The contents of crude ash, fat, and protein, carbohydrate, total fatty acid, and total free amino acid of G-SDH were significantly higher than those of HTA-SDH. The major free amino acids and fatty acids in G-SDH were aspartic acid and oleic acid and those in HTA-SDH were glutamic acid and oleic acid. Compared to G-SDH, higher concentrations of total polyphenols, total flavonoids, Mailliard reaction products, total phenolic acids and total flavonols of HTA-SDH were estimated. After high-temperature aging, the total phenolic and flavonol contents increased from 272.03 to $303.31 \mathrm{\mu g} / \mathrm{g}$ and 310.71 to $372.58 \mu \mathrm{g} / \mathrm{g}$, respectively. The DPPH, ABTS, and hydroxyl radical scavenging activities and the a -glucosidase, $a$-amylase, and pancreatic lipase inhibition activities in HTA-SDH were $85.65 \%$, 89.93\%, and $63.69 \%$, and $61.06 \%, 34.21 \%$, and $64.89 \%$, respectively, which were considerably higher than those in the G-SDH. In addition, HTA-SDH showed the effect of controlling immune function.
\end{abstract}

Key words : balloon flower, phytochemicals, Sibjeondaebohwan, antioxidant, enzyme inhibitory activity

서 론

*Corresponding author. E-mail : kmcho@gntech.ac.kr

Phone : 82-55-751-3272, Fax : 82-55-751-3279

Received 19 June 2019; Revised 22 July 2019; Accepted 25
도라지(Platycodon grandiflorum DC)는 초롱꽃과 (Campanulaceae)에 속하는 다년생 초본식물로서 한국, 일

July 2019.

Copyright (c) The Korean Society of Food Preservation. All rights reserved. 
본 및 중국의 산간지방에 자생하며, 7 월에서 8 월 사이 보라 색 또는 백색으로 피는데, 원줄기 끝에 1 개 또는 여러 개가 위를 향해 달린다. 국내에서는 식품뿐만 아니라 다양한 약 리작용으로 약재로서 이용이 급증하고 있어 재배면적과 생산량이 확대되고 있으며(1), 한방에서는 도라지 뿌리인 길경이 거담, 배농, 진해약, 편도선염, 최유, 감기, 기침 등에 효과가 있다고 알려져 있다 $(2,3)$. 도라지에는 다량의 사포 닌이 함유되어 있는데, 사포닌의 주성분으로는 platycodin $\mathrm{A}, \mathrm{C}, \mathrm{D}$ 와 platycoside A, B, C, D, E가 있다고 알려져 있고 (3), 이 외에도 inulin, betulin, stigmasterol과 여러 종류의 당질 및 섬유질을 함유하고 있다(4). 도라지 효능에 대한 연구로는 장생도라지 추출물의 혈당강하(5), 항암활성 효 과(6,7) 항염증 효과(8), 항비만 효과(9), 항산화 활성 $(10,11)$ 및 간 손상억제(12) 등 다양하게 진행되었다. 특히 우리나라 에서는 식용으로 더 많이 활용되고 있으며, 조리 시 독특한 쓴맛과 향긋한 풍미는 식품으로서의 기호성을 높여주며, 생리활성도 우수한 식품이다(1). 이러한 이유로 도라지의 약리작용과 생리활성을 이용한 다양한 도라지 제품개발에 대한 연구가 수행되어 왔으며 대표적으로 도라지 식혜(13), 도라지 요구르트(14), 도라지 차(15), 도라지 쿠키(16) 등이 있으며, 도라지는 분말, 청, 즙, 환, 분말의 가공식품형태로 시중에 유통·판매되고 있다(7).

생약 규격집에 따르면 십전대보탕은 인삼(Panax ginseng), 백출(Atractylodes japonica), 백복령(Poria cocos), 당귀(Angelica gigas), 천궁(Cnidium offcinale), 숙지황 (Rehmannia glutinosa), 황기(Astragalus membranaceus), 감 초(Glycyrrhiza glabra), 작약(Paeonia lactiflora), 육계 (Cinnamomum cassia)로 구성되어 있다(17). 식품의 열처리 가공은 식품의 저장성과 동시에 품질향상을 위해 사용되었 으나 높은 온도의 열처리 가공 중 영양소 파괴 및 생리활성 물질 손실 등의 문제점들이 제기되어 제한적으로 사용되어 왔었다(4). 그러나 최근 연구에서는 고온(110-150 ${ }^{\circ}$ )에서 열처리 하였을 경우 십전대보탕 재료인 감초(18), 숙지황 (19), 인삼(20), 도라지(4) 또는 흑도라지(21)의 폴리페놀 화합물과 플라보노이드 함량이 증가한다는 연구 결과들이 발표되었다. 십전대보탕 관련 연구 역시 현재 국내에서 다 수 진행된 상태로 십전대보탕의 유산균 발효 연구(22), 십전 대보탕의 뇌신경 세포 보호 활성(17) 등이 보고되었다.

따라서 본 연구에서는 인삼과 유사한 항암(6,7), 항염증 (8), 항산화 $(10,11)$ 및 암세포 증식 억제(23) 등의 효능을 가지면서 인삼보다 경제성이 뛰어난 도라지를 사용하여 십전대보탕 약재 분말에 물과 벌꿀을 첨가하여 혼합하고 고온숙성법을 적용하여 환 형태로 제형하였다. 이후 고온 숙성법을 적용한 십전대보환과 고온숙성법을 적용하지 않 은 일반환의 영양성분, 식품위생미생물 유무 확인과 각종 phytochemicals 함량 및 세포 모델을 이용한 면역 활성 기능 을 비교 분석하였다.

\section{재료 및 방법}

\section{재료 및 미생물 배지}

도라지 함유 십전대보환 제조에 사용된 도라지는 산청군 에서 재배된 2 년근 이상을 사용하였고 이외 백출, 백복령, 당귀, 천궁, 숙지황, 황기, 감초, 작약 및 육계는 산청군 소재 (주자연애제약으로부터 분말 형태로 공급받아 사용하였다. 일반 미생물과 식품위해미생물 측정은 nutrien agar(NA, total viable cells), chlormphenicol 함유 potato dextrose agar(PDAC, total yeast cells), eosin methylene blue agar(EMBA, Escherichia coli), mannitol salt agar(MSA, Stapphylococcus aureus), oxford listeria agar(OLA, Listeria monocytogenes) 및 mannitol egg yolk polymyxin agar(MYPA, Bacillus cereus) 배지를 사용하였고 Difico사 (Detroit, MI, USA)로부터 구입하였다.

\section{시약 및 기기}

Phenolic acid 표준품인 gallic acid, protocatechuic acid, chlorogenic acid, para-hydroxylbenzoic acid, vanillic acid, para-coumraic acid, ferulic acid, veratric acid 및 trans-cinnamic acid와 flavan-3-ols 표준품인 epigallocatechin, catechin, epicatechin, epigallocatechin gallate, vanilin, rutin, catechin gallate, quercetin, naringin, naringenin 및 formonoetin는 Sigma Chemical Co.(St. Louis, MO, USA)에 서 구입하였다. 총 폴리페놀 측정에 사용한 시약은 FolinCicalteu phenol을 사용하였고 총 플라보노이드 측정은 diethyleneglycol을 사용하였으며 Sigma-Aldrich사에서 구 입하였다. 라디칼 소거활성에 사용된 시약은 2,2-diphenyl-1picrylhydrazyl(DPPH), 2,2'-azino-bis (3-ethylbenzothiazoline6-sulfonic acid) diammonium salt(ABTS), potassium ferricyanide, trichloroacetic acid(TCA), thiobarbituric acid, 2-deoxyribose를 사용하였으며 소화효소 저해활성은 para-nitrophenyl-a-D-glucopyranoside(p-NPG) 및 paranitrophenyl-butyrate(p-NPB)를 Sigma-Aldrich사에서 구입 하여 사용하였다. 이 외 분석을 위한 모든 시약은 필요에 따라 1 급을 구입하여 사용하였다. 분광광도계는 spectronic 2D(Spectronic 2D, Thermo Electron Co., Marietta, Ohio, USA)를 사용하였다. High performance liquid chromatography(HPLC)는 HPLC 1200 series(Agilent Co., Santa Clara, CA, USA)를 사용하였고, 검출기는 ultraviolet diode array detector (UV-DAD, HPLC 1200 series, Agilent $\mathrm{Co.}$,)로 분석하였고, 분석 column은 $\mathrm{X}-\mathrm{Bridge}^{\mathrm{TM}} \mathrm{C}_{18}$ column $(4.6 \times 250 \mathrm{~nm}, 5 \mu \mathrm{m}$, lrelande)을 사용하였다. Gas chromatography(Agilent GC 7890, Agilent CO.,)-flame ionization detector(FID)로 분석하였고, 분석 column은 SP-2560 capillary column $(100 \mathrm{~m} \times 0.25 \mathrm{~mm}, 0.20 \mu \mathrm{m}$, Sigma-Aldrich Co.)을 사용하였다. 아미노산 자동분석기는 
Hitachi L-8900(Tokyo, Japan)를 사용하였다.

\section{도라지 함유 십전대보환 제조}

일반 십전대보환(General-sibjeondaebohwan, G-SDH) 제 조는 도라지, 백복령, 백출, 숙지황, 작약, 감초, 황기, 육계, 당귀, 천궁, 및 대추 분말을 각각 $200 \mathrm{~g}$ 에 벌꿀을 $1.8 \mathrm{~kg}$ 을 첨가하여 반죽하고 대환 형태로 성형하였다. 고온숙성 십 전대보환(High temperature aging-sibjeondaebohwan, HTA$\mathrm{SDH}$ ) 제조는 도라지와 10 가지 한약재 분말 $2.2 \mathrm{~kg}$ 에 물 $0.2 \mathrm{~L}$ 와 벌꿀 $1.6 \mathrm{~kg}$ 을 첨가 및 혼합하고 $80^{\circ} \mathrm{C}$ 이상에 약 10 일간 고온숙성 및 농축과정을 거쳐 고를 제조한 후 대환 형태로 성형하였다. 제조된 십전대보환은 일부는 $-70^{\circ} \mathrm{C}$ 에 서 냉동보관하며 필요에 따라 꺼내어 본 실험에 사용하였으 며, 일부는 동결냉동 후 동결건조기로 동결건조하고 분말 을 제조하여 본 실험에 사용하였다.

\section{5 대 영양성분 분석}

영양성분은 제조된 G-SDH 및 $\mathrm{HTA}-\mathrm{SDH}$ 에 대해서 식품 공전법에 준하여 측정하였다. 즉, 수분 함량은 상압가열건 조법으로 측정하였고 조단백과 조지방 함량은 Kheldahl법 과 Soxhelt법으로 측정하였으며, 조회분 함량은 건열회화 법으로 측정하였다. 탄수화물 함량은 상기 각 성분 합의 뺀 값을 \%로 계산하여 나타내었다(23).

\section{지방산 분석}

지방산 분석 역시 식품공전법(24)에 준하여 수행하였다. 지방산 전처리는 $\mathrm{G}-\mathrm{SDH}$ 와 $\mathrm{HTA}-\mathrm{SDH}$ 동결건조 분말 $1 \mathrm{~g}$ 에 $0.5 \mathrm{~N}$ 메탄올성 $\mathrm{NaOH} 3 \mathrm{~mL}$ 를 가해 $100^{\circ} \mathrm{C}$ 의 10 분간 가온하 여 지방산과 글리세롤을 가수분해 시켰다. 이 후 삼불화붕 소 $\left(\mathrm{BF}_{3}\right) 2 \mathrm{~mL}$ 를 가하여 교반한 후 30 분간 다시 가온하여 지방산의 메틸에스테르화를 진행하였다. 반응이 끝난 후 이소옥탄 $1 \mathrm{~mL}$ 를 첨가하고 격렬히 혼합 후 방치시켜 이소 옥탄층만을 회수하여 무수황산나트륨과 함께 탈수한 뒤 $0.45 \mu \mathrm{m}$ membrane filter(Dismic-25CS)로 여과하여 $\mathrm{GC}$ 로 분석하였다. 이동상은 질소 가스를 사용하였으며 이동상의 속도는 $1 \mathrm{~mL} / \mathrm{min}$ 으로 유지하였다. 오븐온도는 $140^{\circ} \mathrm{C}$ 에서 5 분간 유지 후, $180^{\circ} \mathrm{C}$ 까지 1 분당 $20^{\circ} \mathrm{C}$ 만큼 증가시켜 2 분간 유지하였고 $230^{\circ} \mathrm{C}$ 까지 $5^{\circ} \mathrm{C}$ 만큼 증가시켜 최종 35 분간 유지 하였다. Injector와 FID detector의 온도는 각각 $220^{\circ} \mathrm{C}$ 와 24 $0{ }^{\circ} \mathrm{C}$ 로 하였다. 각 실험은 3 회 반복 수행하여 평균값으로 표시하였다.

\section{유리아미노산 분석}

유리아미노산 분석은 G-SDH 및 HTA-SDH 동결건조 분 말 $1 \mathrm{~g}$ 에 증류수 $4 \mathrm{~mL}$ 를 가해 $60^{\circ} \mathrm{C}$ 에서 1 시간 가수분해 시킨 후 $10 \%$-sulfosalicylic acid $1 \mathrm{~mL}$ 를 첨가하여 $4^{\circ} \mathrm{C}$ 에서 2 시간 방치시켜 단백질을 침전시킨 후 3 분간 원심분리 하
여 얻은 상등액을 $0.45 \mu \mathrm{m}$ membrane filter(Dismic-25CS, ToyoroshikaisHTA, Ltd., Tokyo, Japan)로 여과시켜 $60^{\circ} \mathrm{C}$ 에 서 감압 농축하였다. 농축 후 건조물에 대하여 $\mathrm{pH} 2.2$ lithium buffer $2 \mathrm{~mL}$ 씩 첨가하여 $0.45 \mu \mathrm{m}$ membrane filter로 여과시킨 것을 아미노산 자동분석기로 분석하였다(24).

\section{식품위해미생물 분석}

식품위해미생물 검출은 10 단 희석법을 사용하여 측정하 였다. 즉, 십전대보환 시료 $10 \mathrm{~g}$ 에 멸균생리식염수 $90 \mathrm{~mL}$ 로 희석한 후 순차적으로 10 배씩 희석하였다. 희석액 $\left(10^{-1}-10^{-3}\right) 100 \mu \mathrm{L}$ 씩을 $\mathrm{NA}, \mathrm{PDAC}, \mathrm{EMBA}, \mathrm{MSA}, \mathrm{OLA}$ 및 $\mathrm{MYPA}$ 배지를 도말한 후 $30^{\circ} \mathrm{C}(\mathrm{NA}$ 와 $\mathrm{PDAC})$ 혹은 $35^{\circ} \mathrm{C}$ (EMBA, MSA, OLA와 MYPA)에서 48 시간 배양하였다. 총 균수와 효모균수는 각각의 NA와 $\mathrm{PDAC}$ 배지에서 자란 집락을 그대로 계수하였다. 한편 대장균수 $(E$. coli $)$ 는 $\mathrm{EMBA}$ 배지에서 녹색 금속광택을 나타내는 집락을 계수하 였고 황색포도쌍알균수(S. aureus $)$ 은 MSA 배지에서 황색 clear zone을 생성한 집락을 계수하였고 L. monocytogenes 균수는 OLA 배지에서 흑색 집락을 계수하였고 마지막으로 B. cereus 균수는 MYPA 배지에서 분홍색 깃털 모양의 집락 을 계수하여 측정하였다.

\section{십전대보환 추출물 제조}

$\mathrm{G}-\mathrm{SDH}$ 및 $\mathrm{HTA}-\mathrm{SDH}$ 동결건조 분말 $5 \mathrm{~g}$ 에 $80 \%$ 발효주정 $50 \mathrm{~mL}$ 를 첨가하여 상온에서 12 시간 추출하고 $0.45 \mu \mathrm{m}$ membrane filter로 여과하여 상등액을 회수하여 추출물을 제조하였으며 총 폴리페놀 및 총 플라보노이드 함량 측정에 사용하였다. 나머지 추출물은 $60^{\circ} \mathrm{C}$ 에서 감압농축하고 동결 건조하여 건조분말을 얻은 후 추출용매 $(80 \%$ 발효주정 $)$ 에 용해시켜 $1.0,0.5$, 및 $0.25 \mathrm{mg} / \mathrm{mL}$ 농도로 제조하고 그 외 라디칼 소거활성 및 소화효소 저해활성 측정에 사용하였 다.

\section{총 폴리페놀 및 총 플라보노이드 분석}

총 폴리페놀 함량은 Folin-Denis법(25)을 변형하여 측정 하였다. 각각의 추출물 $0.5 \mathrm{~mL}$ 를 시험관에 분주하고 $25 \%$ $\mathrm{Na}_{2} \mathrm{CO}_{3}$ 용액 $0.5 \mathrm{~mL}$ 를 첨가하여 3 분간 정치시킨 후 $2 \mathrm{~N}$ Folin-Ciocalteu phenol 용액 $0.25 \mathrm{~mL}$ 를 첨가 및 혼합한 다음 $30^{\circ} \mathrm{C}$ 에서 1 시간 동안 발색시켰다. 발색된 시료는 $750 \mathrm{~nm}$ 에 서 분광광도계(Spectronic 2D, Thermo Co., Califonia, CL, USA)를 사용하여 흡광도를 측정하였으며 gallic acid를 이 용하여 작성한 표준 검량곡선으로부터 값을 산출하였다.

총 플라보노이드 함량은 Lee 등(26)의 방법과 유사하게 측정하였다. 즉, 각각의 메탄올 추출물 $0.5 \mathrm{~mL}$ 를 시험관에 취하고 여기에 diethylene glycol $1.0 \mathrm{~mL}$ 와 $1 \mathrm{~N} \mathrm{NaOH} 0.01$ $\mathrm{mL}$ 를 가하여 항온수조 $\left(37^{\circ} \mathrm{C}\right)$ 에서 1 시간 방치 후 $420 \mathrm{~nm}$ 에 서 분광광도계로 흡광도를 측정하였다. 이때 총 플라보노 
이드 함량은 rutin을 이용하여 작성한 표준 검량곡선으로부 터 값을 산출하였다.

\section{갈변물질 분석}

갈변물질 함량은 시료 $1 \mathrm{~g}$ 에 3차 증류수 $10 \mathrm{~mL}$ 를 가하여 1 시간 동안 추출한 후 여과하여 비효소적 갈변도법으로 $420 \mathrm{~nm}$ 에서 분광광도계를 사용하여 흡광도를 측정하였다 (27).

\section{Phenolic acids 및 Flavonols 유도체 분석}

Phenolic acids 및 flavonols 화합물 분석은 Cho와 Joo(28) 의 방법을 변형하여 HPLC로 분석하였다. 이동상 용매는 $0.2 \%$ glacial acetic acid 함유 HPLC water (solution A)와 $0.2 \%$ glacial acetic acid 함유 acetonitrile (solution $\mathrm{B}$ )로 분석 하였다. 이동상 조건은 $\mathrm{B}$ 용매 기준으로 $0 \mathrm{~min}-0 \%, 3$ $\min -3 \%, 5$ min-5\%, 8 min-10\%, 10 min-15\%, 13 min-15\%, $14 \min -3 \%, 15 \min -5 \%, 17 \min -8 \%, 19 \min -10 \%, 20$ $\min -15 \%, 22 \min -20 \%, 24 \min -20 \%, 25 \min -5 \%, 26$ $\min -15 \%, 27 \min -20 \%, 28 \min -30 \%, 30 \min -10 \%, 32$ $\min -40 \%$, $35 \min -50 \%, 36 \min -60 \%, 37 \min -30 \%$, $38 \mathrm{~min}$ 40\%, 40 min-50\%, 45 min-60\%, 55 min- $80 \%, 60$ min-90\% 및 $65 \mathrm{~min}-100 \%$ 로 유지하였다. 이때 분석 시료는 $20 \mu \mathrm{L}$ 를 주입하였고 이동상의 속도는 $30^{\circ} \mathrm{C}$ 에서 $1 \mathrm{~mL} / \mathrm{min}$ 으로 유지 하였고 phenolic acids 화합물은 $\mathrm{DAD}$ 검출기의 흡광도 280 $\mathrm{nm}$ 및 flavan-3-ols 화합물은 $270 \mathrm{~nm}$ 에서 분석하였다.

\section{Radical 소거활성 측정}

DPPH radical 소거활성은 Cho 등(29)의 방법에 따라 측정 하였다. $1.5 \times 10^{4} \mathrm{mM} \mathrm{DPPH}$ 용액 $0.8 \mathrm{~mL}$ 와 추출물 $0.2 \mathrm{~mL}$ 를 가하여 30 분간 암실에서 반응시킨 후 분광광도계를 이용하 여 $525 \mathrm{~nm}$ 에서 흡광도를 측정하였다. 음성 대조구 실험은 시료 대신에 에탄올을 $0.2 \mathrm{~mL}$ 를 취하여 실험하였으며, $\mathrm{DPPH}$ 라디칼 소거활성은 실험구와 음성 대조구의 흡광도 를 구하여 상대적 비교치(\%)로 나타내었다.

ABTS radical 소거활성 역시 Cho 등(29)의 방법에 따라 $7 \mathrm{mM}$ ABTS 용액과 $2.45 \mathrm{mM}$ potassium persulfate을 $1: 1(\mathrm{v} / \mathrm{v})$ 로 섞고, 암실에서 12 16시간을 방치시켜 ABTS 라 디칼 $\left(\mathrm{ABTS}^{+}{ }^{*}\right.$ )을 형성시켰다. 이후 $732 \mathrm{~nm}$ 에서 흡광도 값 이 $0.7 \pm 0.03$ 이 되도록 메탄올로 희석하여 사용하였다. 적당 히 희석된 $\mathrm{ABTS}$ 용액 $0.9 \mathrm{~mL}$ 와 추출물 $0.1 \mathrm{~mL}$ 를 섞고 3 분 후 분광광도계를 이용하여 $732 \mathrm{~nm}$ 에서 흡광도를 측정 하였다. 음성 대조구 실험은 시료 대신에 메탄올을 $0.1 \mathrm{~mL}$ 를 취하여 실험하였으며, ABTs 라디칼 소거활성은 상기 기술된 DPPH 라디칼 소거활성과 동일한 방법으로 나타내 었다.

Hydroxyl $(\cdot \mathrm{OH})$ radical 소거활성은 Cho 등(29)의 방법에 따라 $10 \mathrm{mM} \mathrm{FeSO} \cdot 7 \mathrm{H}_{2} 0$-EDTA $0.2 \mathrm{~mL}, 10 \mathrm{mM}$ 2-deoxyribose $0.2 \mathrm{~mL}, 10 \mathrm{mM} \mathrm{H} \mathrm{O}_{2} 0.2 \mathrm{~mL}$, 시료 $1.4 \mathrm{~mL}$ 를 혼합하고 $37^{\circ} \mathrm{C}$ 에서 4 시간 동안 반응시켰다. 이 혼합액에 $1 \%$ thiobarbituric acid와 $2.8 \%$ trichloroaceric acid를 각각 $1 \mathrm{~mL}$ 씩 가하여 $100^{\circ} \mathrm{C}$ 에서 20 분간 발색시켜 $520 \mathrm{~nm}$ 에서 흡광도를 측정하였다. 음성 대조구는 시료 대신에 PBS 완 충액 $\left(\mathrm{NaCl} 8.76 \mathrm{~g}, \mathrm{NaH}_{2} \mathrm{PO}_{3} 0.11 \mathrm{~g}, \mathrm{Na}_{2} \mathrm{HPO}_{3} 0.596 \mathrm{~g}\right)$ 을 사용하였다.

모든 라디칼 소거활성은 아래와 같은 식에 대입하여 백 분율(\%)로 나타내었다.

$$
\text { 라디칼 소거활성(\%)=(1- } \left.\frac{\text { 음성 대조구 흡광도 }}{\text { 실험구 흡광도 }}\right) \times 100
$$

\section{소화효소 저해활성 측정}

a-Glucosidase 저해활성은 $200 \mathrm{mM}$ sodium phosphate buffer(pH 6.8) $50 \mu \mathrm{L}$ 시료와 a-glucosidase 효소 $50 \mu \mathrm{L}$ 를 첨가하여 $37^{\circ} \mathrm{C}$ 에서 10 분간 예비 배양한 후 sodium phosphate buffer(pH 6.8) $100 \mu \mathrm{L}$ 와 $5 \mathrm{mM}$ p-nitrophenol-a -D-glucopyranoside(p-NPG)을 $100 \mu \mathrm{L}$ 를 가하여 $37^{\circ} \mathrm{C}$ 에서 10 분간 반응시켰다. 이 반응물에 $100 \mathrm{mM} \mathrm{Na} \mathrm{CO}_{3} 750$ $\mu \mathrm{L}$ 를 첨가하여 반응을 정지시키고 $420 \mathrm{~nm}$ 에서 흡광도를 측정하고 저해율을 계산하였다(27).

a-Amylase 저해활성은 각 추출물 $50 \mu \mathrm{L}$ 를 시험관에 분주 한 후 a-amylase $(1.0 \mathrm{U} / \mathrm{mL})$ 효소용액 $50 \mu \mathrm{L}$ 와 $200 \mathrm{mM}$ sodium phosphate buffer $\left(\mathrm{pH}\right.$ 6.8) $50 \mu \mathrm{L}$ 를 첨가하여 $37^{\circ} \mathrm{C}$ 에 서 10 분간 예비 반응을 실시하였다. 이 반응액에 $200 \mathrm{mM}$ sodium phosphate buffer(pH 6.8)에 녹인 $1 \%$ 전분용액을 $0.25 \mathrm{~mL}$ 를 가하고 다시 $37^{\circ} \mathrm{C}$ 에서 10 분간 반응을 실시하였 다. 이후에는 $0.5 \mathrm{~N} \mathrm{NaOH}$ 및 $30 \%$ potasium sodium tartrate를 용해한 $48 \mathrm{mM}$ DNS 시약을 $0.25 \mathrm{~mL}$ 첨가하여 $100^{\circ} \mathrm{C}$ 에서 20 분간 끓여 발색 및 냉각시킨 후 $570 \mathrm{~nm}$ 에서 흡광도를 측정하였다(30).

Pancreatic lipase 저해활성은 $200 \mathrm{mM}$ sodium phosphate buffer(pH 6.8) $50 \mu \mathrm{L}$ 에 추출물 $50 \mu \mathrm{L}$, pancreatic-lipase $(1.0$ $\mathrm{U} / \mathrm{mL}$ ) 효소용액 $50 \mu \mathrm{L}$ 를 혼합하여 $37^{\circ} \mathrm{C}$ 에서 10 분간 예비 반응시켰다. 반응 후 인산나트륨 완충용액에 녹인 p-NPB(5 $\mathrm{mM}) 100 \mu \mathrm{L}$ 를 가하여 동일하게 10 분간 반응시킨 후 100 $\mathrm{mM} \mathrm{Na}_{2} \mathrm{CO}_{3} 750 \mu \mathrm{L}$ 를 가해 반응을 종료시킨 후 $420 \mathrm{~nm}$ 에서 흡광도를 측정하였다(31).

모든 효소 저해활성의 음성 대조구는 시료 대신에 추출 용매를 취하였으며 시료용액의 첨가구와 무첨가구 사이의 흡광도 차이를 백분율(\%)로 나타내었다.

$$
\text { 소화효소 저해활성 }(\%)=\left(1-\frac{\text { 음성 대조구 흡광도 }}{\text { 실험구 흡광도 }}\right) \times 100
$$




\section{면역세포 활성효과}

마우스 대식세포인 RAW 264.7은 penicillin/streptomycin (Gibco) 100 unit $/ \mathrm{mL}$ 와 $10 \%$ FBS이 함유된 $\mathrm{DMEM}$ (HyClone) 배지를 사용하여 $37^{\circ} \mathrm{C}$ 에서 $5 \% \mathrm{CO}_{2}$ incubator에 서 배양하면서 2 일에 한 번씩 계대배양 하였다. NO 생성능 측정은 RAW264.7 cell을 분주하고 24시간 후에 십전대보 환 추출물과 LPS를 24시간 자극시키고 세포배양 상층액을 얻어 96-well plate에 griess 시약과 함께 넣어 반응시킨 후 흡광도 $540 \mathrm{~nm}$ 에서 측정하였다. Western blot 분석은 RAW264.7 대식 세포주를 분주하여 24시간 배양시킨 후 serum free media로 동안 완전히 부착시키고. PBS에 희석된 십전대보환 추출물을 $0.5,1$ 및 $5 \mathrm{mg} / \mathrm{mL}$ 의 농도로 처리하였 고, 양성대조군인 LPS 또한 $0.1 \mathrm{\mu g} / \mathrm{mL}$ 농도로 처리하였다. 30분 후 세포를 수집하여 PBS로 3회 세척하고 NE-PERTM Nuclear Cytoplasmic Extraction Reagents kit (Thermo Scientific, Rockford, IL, USA)를 사용하여 세포질과 핵 내의 단백질을 순차적으로 분리하였다. 분리된 단백질은 $\mathrm{BCA}$ protein detection kit (Thermo Scientific Inc. USA)을 사용하 여 단백질을 정량하였다. 한편, well 당 $20 \mu \mathrm{g}$ 의 cell lysate를 $10 \%$ polyacrylamide gel에 각각 전개하여 SDS-PAGE로 변 성 분리하였다. 이를 poly-vinylidene difluoride membrane (Millipore, Merck KGaA, Darmstadt, Germany)으로 전환하 였고, membrane은 antibody의 비특이적 결합을 방지하기 위해 blocking solution (skim milk 5\%) $20 \mathrm{~mL}$ 에서 2시간 동안 방치한 후 TBST $(20 \mathrm{nM}$ tris- $\mathrm{HCl}, 150 \mathrm{mM} \mathrm{NaCl}, 0.05 \%$ Tween-20, $\mathrm{pH}$ 7.5)로 10분씩 3회 세척하고 iNOS, COX-2, TNF-a 및 $\beta$-actin의 발현량을 측정하기 위해 1차 항체 (Cell signaling Technology, Danvers, MN, USA)를 1:1,000으로 희석하여 $4^{\circ} \mathrm{C}$ 에서 24 시간 반응시키고, TBST로 10 분간 3 회 세척하였다. 이후 2차 항체 (abcam, Cambridge, UK)를 $1: 5,000$ 으로 희석하여 2시간 동안 반응시키고, TBST로 10 분간 5회 세척하였다. Electrochemiluminescence (ECL; Millipore Merck $\mathrm{KGaA}$ ) reagent를 이용하고, LAS-4000 (GE Healthcare Life Sciences, Marlborough, MA, USA) 이미지 장치를 이용하여 분석하였다(32).

\section{통계처리}

모든 실험은 3회 반복 수행하여 평균표준편차로 나타 내었다. 각 시료 분석 결과에 대한 유의성 검정은 분산 분석 후 $\mathrm{p}<0.05$ 수준에서 Duncan's multiple range test를 실시하였 다.

\section{결과 및 고찰}

십전대보환의 5 대 영양성분 함량

$\mathrm{G}-\mathrm{SDH}$ 와 $\mathrm{HTA}-\mathrm{SDH}$ 의 영양성분 분석 결과는 Table 1 에
나타내었다. 수분은 G-SDH(18.6 g/100 g)보다는 HTA$\mathrm{SDH}(23.4 \mathrm{~g} / 100 \mathrm{~g})$ 가 좀 더 많은 함유량을 나타내었고 조단 백 함량 역시 $4.8 \mathrm{~g} / 100 \mathrm{~g}$ 으로 G-SDH(4.4 g/100 g)보다 많았 으나 조지방 함량은 G-SDH가 $1.0 \mathrm{~g} / 100 \mathrm{~g}$ 이었고 HTA-SDH 는 $0.6 \mathrm{~g} / 100 \mathrm{~g}$ 을 함유하고 있었다. 조회분 또한 G-SDH(1.7 $\mathrm{g} / 100 \mathrm{~g})$ 가 HTA-SDH$(1.4 \mathrm{~g} / 100 \mathrm{~g})$ 보다 약간 더 많은 함유량 을 나타내었다. 대체적으로 5 대 영양성분은 $\mathrm{G}-\mathrm{SDH}$ 가 좀 더 많은 양을 함유하고 있었고 이에 따라 탄수화물 함량 역시 $\mathrm{G}-\mathrm{SDH}$ 가 $73.9 \%$ 로 HTA-SDH(70.2\%)보다 많은 것으 로 나타났으나 큰 유의적 차이는 없었다(Table 1).

Table 1. Proximate analysis of Sibjeondaebohwan with balloon flower

\begin{tabular}{ccc}
\hline \multirow{2}{*}{ Contents $(\mathrm{g} / 100 \mathrm{~g})$} & \multicolumn{2}{c}{ Sibjeondaebohwan } \\
\cline { 2 - 3 } & $\mathrm{G}-\mathrm{SDH}^{\mathrm{1}}$ & HTA-SDH \\
\hline Moisture & $18.6 \pm 0.93^{\mathrm{b3})}$ & $23.4 \pm 1.17^{\mathrm{a}}$ \\
Crude protein & $4.8 \pm 0.24^{\mathrm{a}}$ & $4.4 \pm 0.22^{\mathrm{a}}$ \\
Crude fat & $1.0 \pm 0.05^{\mathrm{a}}$ & $0.6 \pm 0.03^{\mathrm{a}}$ \\
Crude ash & $1.7 \pm 0.09^{\mathrm{a}}$ & $1.4 \pm 0.07^{\mathrm{a}}$ \\
Carbohydrate & $73.9 \pm 3.70^{\mathrm{a}}$ & $70.2 \pm 3.51^{\mathrm{a}}$ \\
\hline
\end{tabular}

${ }^{1)} \mathrm{G}-\mathrm{SDH}$, general Sibjeondaebohwan.

${ }^{2)} \mathrm{HTA}-\mathrm{SDH}$, high temperature aging Sibjeondaebohwan.

${ }^{3}$ All values are presented as the mean \pm SD of triplicate determination. All values within a column with different superscript letters are significantly from each other at $p<0.05$ by Duncan's multiple range test.

\section{십전대보환의 지방산 함량}

십전대보환의 지방산을 분석한 결과는 Table 2에 나타내 었다. G-SDH의 경우 포화지방산 중 stearic $\operatorname{acid}(\mathrm{C} 18: 0)$ 및 behenic $\operatorname{acid}(\mathrm{C} 22: 0)$ 가 검출되지 않았고 $\mathrm{HTA}-\mathrm{SDH}$ 는 palmitic $\operatorname{acid}(11.8 \mathrm{mg} / 100 \mathrm{~g})$, stearic $\operatorname{acid}(2.0 \mathrm{mg} / 100 \mathrm{~g})$, 및 behenic $\operatorname{acid}(0.8 \mathrm{mg} / 100 \mathrm{~g})$ 모두 검출 되었다. 한편 G-SDH 에서는 불포화지방산 중 a-linoleic $\operatorname{acid}(\mathrm{C} 18: 3 \mathrm{n} 3)$ 와 docosahexaenoic acid(C22:6n3)가 검출되지 않은 반면 고온 숙성에 따라 제조된 HTA-SDH는 불포화지방산이 모두 검 출되었다. G-SDH의 주요 불포화지방산은 oleic $\operatorname{acid}(40.4$ $\mathrm{mg} / 100 \mathrm{~g}$ )였으나 HTA-SDH의 경우에는 oleic acid가 6.6 $\mathrm{mg} / 100 \mathrm{~g}$ 으로 급격히 감소한 것으로 나타났다. 또한 $\mathrm{G}-\mathrm{SDH}$ 의 linoleic acid 함량은 $24.8 \mathrm{mg} / 100 \mathrm{~g}$ 이었으나 HTA-SDH의 linoleic acid 함량은 $40.6 \mathrm{mg} / 100 \mathrm{~g}$ 으로 고온숙 성에 따라 증가한 것으로 나타났다. 이 외에도 a-linoleic acid와 docosahexaenoic acid가 각각 고온숙성 후 1.9 및 3.1 $\mathrm{mg} / 100 \mathrm{~g}$ 으로 약간 증가하는 경향을 나타내었다. 한편 지방 산 총 함량은 HTA-SDH(66.8 mg/100 g)보다 G-SDH(78.8 $\mathrm{mg} / 100 \mathrm{~g}$ )가 좀 더 높은 것으로 나타났고 이는 고온 처리에 의해 포화 및 불포화지방산 함량이 약간 감소하는 경향을 나타내었다. 
Table 2. Fatty acid contents in Sibjeondaebohwan with balloon flower

\begin{tabular}{ccc}
\hline \multirow{2}{*}{ Fatty acid contents ${ }^{1)}(\mathrm{mg} / 100 \mathrm{~g})$} & \multicolumn{2}{c}{ Sibjeondaebohwan } \\
\cline { 2 - 3 } Gaturated fatty acids & HTA-SDH ${ }^{3}$ \\
\hline C16:0 Palmitic acid & $13.6 \pm 0.68^{\mathrm{a}}$ & $11.8 \pm 0.59^{\mathrm{a}}$ \\
C18:0 Stearic acid & $\mathrm{ND}^{4)}$ & $2.0 \pm 0.01^{\mathrm{a}}$ \\
C22:0 Behenic acid & $\mathrm{ND}$ & $0.8 \pm 0.04^{\mathrm{a}}$ \\
Total & $13.6 \pm 0.68^{\mathrm{a}}$ & $14.6 \pm 0.73^{\mathrm{a}}$ \\
\hline \multirow{3}{c}{ Unsaturated fatty acids } \\
C18:1n9c Oleic acid & $40.4 \pm 2.02^{\mathrm{a}}$ \\
C18:2n6c Linoleic acid & $24.8 \pm 1.24^{\mathrm{b}}$ & $6.6 \pm 0.33^{\mathrm{b}}$ \\
C18:3n3 a-Linolenic acid & $\mathrm{ND}$ & $40.6 \pm 2.03^{\mathrm{a}}$ \\
C22:6n3 Docosahexaenoic acid & $\mathrm{ND}$ & $3.9 \pm 0.10^{\mathrm{a}}$ \\
Total & $65.2 \pm 3.26^{\mathrm{a}}$ & $52.2 \pm 2.16^{\mathrm{a}}$ \\
\hline Total fatty acids & $78.8 \pm 3.94^{\mathrm{a}}$ & $66.8 \pm 3.34^{\mathrm{b}}$
\end{tabular}

${ }^{1)}$ All values are presented as the mean \pm SD of triplicate determination. All values within a column with different superscript letters are significantly from each other at $p<0.05$ by Duncan's multiple range test

${ }^{2)}$ G-SDH: General Sibjeondaebohwan.

${ }^{3)}$ HTA-SDH: High temperature aging Sibjeondaebohwan.

${ }^{4} \mathrm{ND}$ : not detected.

\section{십전대보환의 유리아미노산 함량}

유리아미노산 분석 결과 일반아미노산 28종류 중 phosphoserine, phosphoetanolamine, urea, proline, aminoadipic acid, a-aminobutyric acid, 1-methylhistidine, 3-methylhistidine, 및 carnosine이 검출되지 않아 총 19 종류가 검출되었고 필수아미노산은 8종류(threonine, methionine, isoleucine, leucine, phenylalanine, lysine, histidine) 모두 검출되었다 (Table 3). G-SDH의 주요 아미노산은 arginine이었으며 고 온숙성 처리에 따라 $301.62 \mathrm{mg} / 100 \mathrm{~g}$ 에서 $1.80 \mathrm{mg} / 100 \mathrm{~g}$ 으 로 급격히 감소하였고 일반아미노산 총 함량 역시 820.01 $\mathrm{mg} / 100 \mathrm{~g}$ 이었으나 HTA-SDH의 경 우 $92.42 \mathrm{mg} / 100 \mathrm{~g}$ 으로 대부분 감소하였고 taurine $(6.46 \rightarrow 23.04 \mathrm{mg} / 100 \mathrm{~g})$ 을 제외 한 모든 일반아미노산들은 고온숙성 처리에 따라 크게 감소 하는 결과를 나타내었다. 필수아미노산의 경우에는 methionine, isoleucine, phenylalanine, lysine, 및 histidine이 각각 $3.64 \rightarrow 5.47 \mathrm{mg} / 100 \mathrm{~g}, 7.03 \rightarrow 10.31 \mathrm{mg} / 100 \mathrm{~g}, 5.76$ $\rightarrow 13.09 \mathrm{mg} / 100 \mathrm{~g}, 5.52 \rightarrow 8.71 \mathrm{mg} / 100 \mathrm{~g}$, 및 $8.62 \rightarrow 15.39$ $\mathrm{mg} / 100 \mathrm{~g}$ 으로 고온숙성 시 조금씩 증가하였고 threonine $(9.22 \rightarrow 5.68 \mathrm{mg} / 100 \mathrm{~g})$, valine $(18.67 \rightarrow 3.64 \mathrm{mg} / 100 \mathrm{~g})$, 및 leucine $(6.77 \mathrm{mg} / 100 \mathrm{~g} \rightarrow \mathrm{ND})$ 은 감소하는 경향을 나타내 었다. 고온숙성 처리 시 대부분의 유리아미노산이 감소하 는 결과로 유리아미노산 총 함량 역시 $885.24 \mathrm{mg} / 100 \mathrm{~g}$ 에서 $154.71 \mathrm{mg} / 100 \mathrm{~g}$ 으로 대부분 감소하는 경향을 나타내었다 (Table 3).

고온숙성과 같은 열처리나 증숙 과정 중에는 amino-
Table 3. Free amino acid contents in Sibjeondaebohwan with balloon flower

\begin{tabular}{|c|c|c|}
\hline \multirow{2}{*}{ Contents $^{1)}(\mathrm{mg} / 100 \mathrm{~g})$} & \multicolumn{2}{|c|}{ Sibjeondaebohwan } \\
\hline & G-SDH ${ }^{2)}$ & HTA-SDH ${ }^{3)}$ \\
\hline \multicolumn{3}{|c|}{ Non-essential amino acids } \\
\hline Taurine & $6.46 \pm 0.32^{\mathrm{b}}$ & $23.04 \pm 1.15^{\mathrm{a}}$ \\
\hline Aspartic acid & $48.55 \pm 2.43^{\mathrm{a}}$ & $36.18 \pm 1.81^{b}$ \\
\hline Serine & $11.91 \pm 0.60^{\mathrm{a}}$ & $2.84 \pm 0.14^{\mathrm{b}}$ \\
\hline Glutamic acid & $50.41 \pm 2.52^{\mathrm{a}}$ & $6.18 \pm 0.31^{\mathrm{b}}$ \\
\hline Sarcosine & $2.50 \pm 0.13^{\mathrm{a}}$ & $\mathrm{ND}^{4)}$ \\
\hline Glycine & $3.62 \pm 0.18^{\mathrm{a}}$ & $1.65 \pm 0.08^{b}$ \\
\hline Alanine & $29.40 \pm 1.47^{\mathrm{a}}$ & $9.51 \pm 0.48^{\mathrm{b}}$ \\
\hline Citrulline & $1.89 \pm 0.09^{\mathrm{a}}$ & ND \\
\hline Cystine & $8.31 \pm 0.42^{\mathrm{a}}$ & $2.87 \pm 0.14 b$ \\
\hline Cystathionine & $2.20 \pm 0.11^{\mathrm{a}}$ & $\mathrm{ND}$ \\
\hline Tyrosine & $5.90 \pm 0.30^{\mathrm{a}}$ & $1.93 \pm 0.10^{b}$ \\
\hline$\beta$-alanine & $4.29 \pm 0.21^{\mathrm{a}}$ & $1.83 \pm 0.09^{b}$ \\
\hline$\beta$-aminoisobutyric acid & $7.48 \pm 0.37^{\mathrm{a}}$ & $0.59 \pm 0.03^{b}$ \\
\hline$\gamma$-aminobutyric acid & $22.01 \pm 1.10^{\mathrm{a}}$ & $1.50 \pm 0.08^{b}$ \\
\hline AminoetHTAnol & $4.40 \pm 0.22^{\mathrm{a}}$ & $2.02 \pm 0.10^{b}$ \\
\hline Hydroxyproline & $0.21 \pm 0.01^{\mathrm{a}}$ & $\mathrm{ND}$ \\
\hline Ornithine & $1.00 \pm 0.05^{\mathrm{a}}$ & $0.48 \pm 0.02^{\mathrm{b}}$ \\
\hline Anserine & $307.85 \pm 15.39^{\mathrm{a}}$ & $\mathrm{ND}$ \\
\hline Arginine & $301.62 \pm 15.08^{\mathrm{a}}$ & $1.80 \pm 0.09^{b}$ \\
\hline Total & $820.01 \pm 41.00^{\mathrm{a}}$ & $92.42 \pm 4.62^{\mathrm{b}}$ \\
\hline \multicolumn{3}{|c|}{ Essential amino acids } \\
\hline Threonine & $9.22 \pm 0.46^{\mathrm{a}}$ & $5.68 \pm 0.28^{b}$ \\
\hline Valine & $18.67 \pm 0.93^{\mathrm{a}}$ & $3.64 \pm 0.18^{b}$ \\
\hline Methionine & $3.64 \pm 0.18^{b}$ & $5.47 \pm 0.27^{\mathrm{a}}$ \\
\hline Isoleucine & $7.03 \pm 0.35^{b}$ & $10.31 \pm 0.52^{\mathrm{a}}$ \\
\hline Leucine & $6.77 \pm 0.34^{\mathrm{a}}$ & ND \\
\hline Phenylalanine & $5.76 \pm 0.29^{b}$ & $13.09 \pm 0.65^{\mathrm{a}}$ \\
\hline Lysine & $5.52 \pm 0.28^{\mathrm{b}}$ & $8.71 \pm 0.44^{\mathrm{a}}$ \\
\hline Histidine & $8.62 \pm 0.43^{b}$ & $15.39 \pm 0.77^{\mathrm{a}}$ \\
\hline Total & $65.23 \pm 3.26^{\mathrm{a}}$ & $62.29 \pm 3.11^{\mathrm{a}}$ \\
\hline Total amino acids & $885.24 \pm 44.26^{\mathrm{a}}$ & $154.71 \pm 7.74^{b}$ \\
\hline
\end{tabular}

${ }^{1)}$ All values are presented as the mean $\pm \mathrm{SD}$ of triplicate determination. All values within a column with different superscript letters are significantly from each other at $\mathrm{p}<0.05$ by Duncan's multiple range test.

${ }^{2)} \mathrm{G}-\mathrm{SDH}$ : General Sibjeondaebohwan.

${ }^{3)}$ HTA-SDH: High temperature aging Sibjeondaebohwan.

${ }^{4} \mathrm{ND}$ : not detected.

carbonyl 반응 중 특히 maillard 반응에 의해 유리아미노산 의 손실이 크게 일어난 것으로 사료된다. 특히 $\operatorname{Van}$ Boekel(33)의 연구에서는 염기성 아미노산인 arginine과 lysine이 amino-carbonyl 반응에 가장 먼저 참여하며 나머지 
아미노산들이 순차적으로 반응에 참여하여 종래에는 아미 노산 함량이 크게 감소한다고 보고하였고 이러한 결과는 본 연구와도 일치하였다.

\section{십전대보환의 식품위해미생물}

$\mathrm{G}-\mathrm{SDH}$ 와 HTA-SDH의 식품위해미생물 검출을 실시한 결과는 Table 4에 나타내었다. HTA-SDH의 경우 식품위해 미생물인 E. coli, S. aureus, L. monocytogenes, 및 B. cereus 균주 모두 검출되지 않았다. 이는 위해미생물 세포들이 고 온에 의해 사멸된 것으로 추정된다. 한편 $\mathrm{G}-\mathrm{SDH}$ 의 경우

Table 4. Comparison of food-pathogenic microorganisms in Sibjeondaebohwan with balloon flower

\begin{tabular}{ccc}
\hline \multirow{2}{*}{ Viable cell numbers $^{1)}(\log \mathrm{CFU} / \mathrm{g})$} & \multicolumn{2}{c}{ Sibjeondaebohwan } \\
\cline { 2 - 3 } & $\mathrm{G}-\mathrm{SDH}^{2)}$ & $\left.\mathrm{HTA}^{2} \mathrm{SDH}^{3}\right)$ \\
\hline Total viable cells & $3.38 \pm 0.17^{\mathrm{a}}$ & $1.07 \pm 0.05^{\mathrm{b}}$ \\
Total yeast cells & $1.22 \pm 0.06^{\mathrm{a}}$ & $\mathrm{ND}^{4)}$ \\
Eschenichia coli & $\mathrm{ND}$ & $\mathrm{ND}$ \\
Salmonella sp. & $\mathrm{ND}$ & $\mathrm{ND}$ \\
Staphylrococcus aureus & $\mathrm{ND}$ & $\mathrm{ND}$ \\
Listeria monocytogenes & $\mathrm{ND}$ & $\mathrm{ND}$ \\
Bacillus cereus & $1.60 \pm 0.08 \mathrm{a}$ & $\mathrm{ND}$ \\
\hline
\end{tabular}

${ }^{1)}$ All values are presented as the mean $\pm \mathrm{SD}$ of triplicate determination. All values within a column with different superscript letters are significantly from each other at $\mathrm{p}<0.05$ by Duncan's multiple range test.

${ }^{2)}$ G-SDH: General Sibjeondaebohwan.

${ }^{3} \mathrm{HTA}$-SDH: High temperature aging Sibjeondaebohwan.

${ }^{4} \mathrm{ND}$ : not detected.
효모 균주는 $1.22 \log \mathrm{CFU} / \mathrm{g}$ 의 세포수가 검출되었고 $B$. cereus 균주는 $1.60 \log \mathrm{CFU} / \mathrm{g}$ 의 세포수가 검출되었다. 총 생균수는 G-SDH가 $3.38 \log \mathrm{CFU} / \mathrm{g}$ 으로 미생물 세포수가 검출되었고 $\mathrm{HTA}-\mathrm{SDH}$ 는 $1.07 \log \mathrm{CFU} / \mathrm{g}$ 가 검출되었다 (Table 4).

$\mathrm{Kim}$ 등(34)의 십전대보탕의 장기보관 중 품질변화 연구 에서는 십전대보탕 전탕액을 이용하여 대장균, 황색포도상 구균, 녹농균 살모넬라균, 및 진균류 검출 결과 호기성균과 진균류는 검출되지 않음을 보고하였다. 고온숙성으로 제조 된 도라지 함유 십전대보환은 인삼보다 가격 경쟁력이 뛰어 난 도라지를 사용함으로서 고온숙성에 따른 제조 원가 상승 을 어느 정도 대처할 수 있을 뿐만 아니라 미생물에 대한 안전성 확보로 저장 기간 즉, 유통 기간 설정을 장기간 할 수 있어 기업의 유통에 대한 경제적 부담을 감소시키고 소비자에게 안전성에 대한 신뢰성을 부여할 수 있을 것으로 판단된다.

\section{십전대보환의 총 폴리페놀, 총 플라보노이드 및 갈변물질 함량}

십전대보환의 총 폴리페놀, 총 플라보노이드와 갈변물질 함량을 비교한 결과는 Fig. 1에 나타내었다. 총 폴리페놀 및 플라보노이드 함량은 각각 $1.56 \rightarrow 2.21 \mathrm{mg} / \mathrm{g}$ (Fig. 1A) 및 $0.16 \rightarrow 0.23 \mathrm{mg} / \mathrm{g}$ (Fig. 1B)로 고온숙성 처리 시 약간 증가하였다. 갈변물질 역시 $\mathrm{G}-\mathrm{SDH}$ 의 경우 3.31 의 흡광도 값을 나타냈으나 고온 숙성 후 갈변화 반응에 의해 HTA-SDH는 좀 더 짙은 색감과 함께 4.04의 흡광도 값을 나타내었다(Fig. 1C).
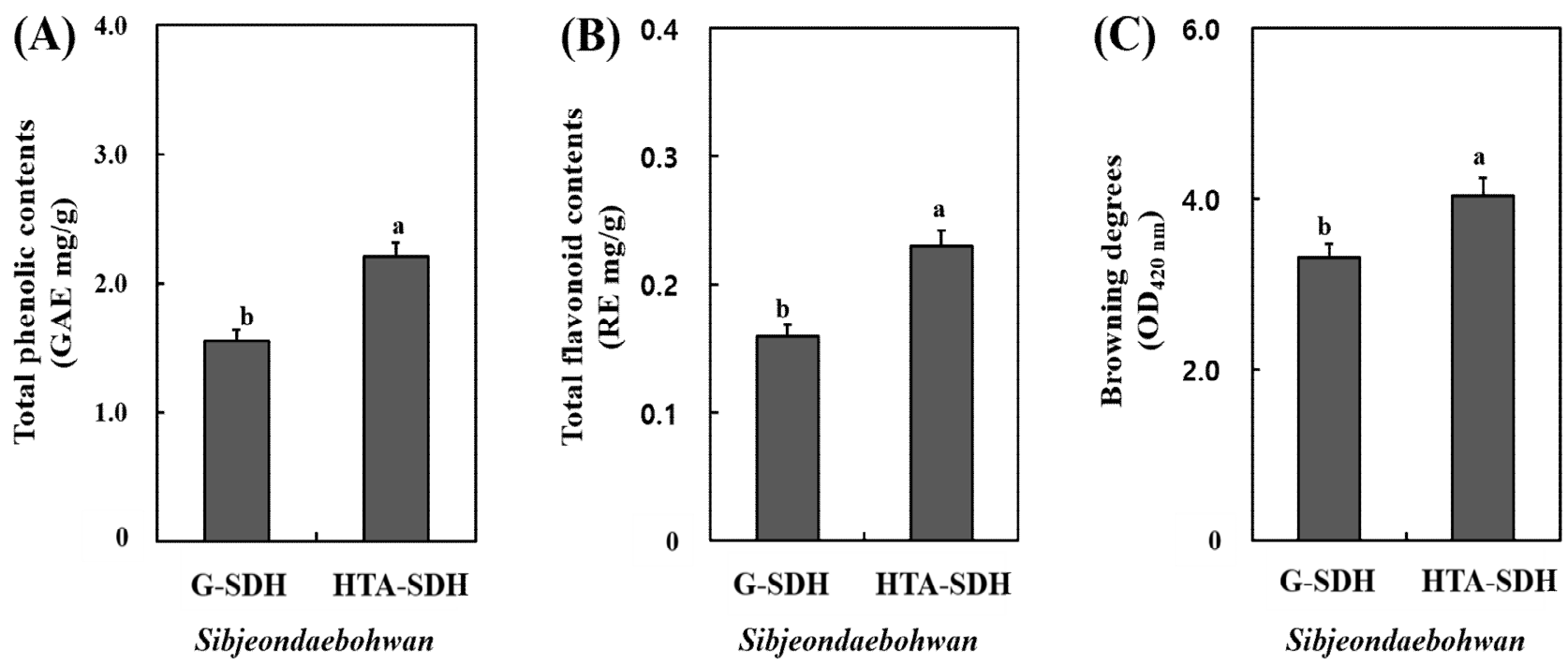

Fig. 1. Comparison of total phenolic and flavonoid contents and browning degrees in Sibjeondaebohwan with balloon flower.

A, total phenolic contents; B, total flavonoid contents; C, Browning degrees.

G-SDH, general Sibjeondaebohwan, HTA-SDH, high temperature aging Sibjeondaebohwan

All values are means of determination in three independent experiments.

All values within a column with different superscript letters are significantly different from each other at $p<0.05$ by Duncan's multiple range test. 
고온에서의 숙성은 총 폴리페놀, 총 플라보노이드 및 갈 변물질과 같은 생리활성 물질을 증가시키며 이 역시 고분자 화합물들이 열처리에 의해 저분자 화합물로 분해된 것으로 추정된다(4). 특히, 갈변물질의 증가 현상은 도라지와 십전 대보환 재료에 사용된 한약재들이 함유하고 있는 아미노산 들이 mailliard 반응에 의한 것으로 판단되었다. 십전대보탕 의 재료 중 하나인 감초 추출물의 항산화 활성에 관한 Woo 등(18)의 연구 결과에서는 열처리를 하지 않은 대조구 $(692.23 \mathrm{mg} / 100 \mathrm{~g})$ 보다 고온 $\left(150^{\circ} \mathrm{C}\right)$ 에서 열처리를 한 경우 $1,391.51 \mathrm{mg} / 100 \mathrm{~g}$ 으로 열처리 온도가 높을수록 폴리페놀 함량 역시 증가한다고 보고하였고 이는 본 연구와도 유사하 였다. Yang 등(20) 역시 십전대보탕 재료에 속하는 인삼을 고온고압처리 하였을 시 $110-140^{\circ} \mathrm{C}$ 까지는 처리시간이 증가 할수록 폴리페놀 함량 역시 증가하며 특히 온도에 비례하여 $150^{\circ} \mathrm{C}$ 에서는 $29.46 \mathrm{mg} / \mathrm{g}$ 까지 증가하는 결과를 보고하였고 Song 등(19)은 숙지황에서 동일한 결과를 보고하였다. 한편 Hwang 등(4)은 십전대보탕 재료 중 하나인 도라지 에탄올 추출물의 총 폴리페놀 함량을 측정한 결과 $0.59 \mathrm{mg} / \mathrm{g}$ 이었으 나 고온 $\left(110-150^{\circ} \mathrm{C}\right)$ 에서 열처리 시 최대 $7.34 \mathrm{mg} / \mathrm{g}$ 의 수준까 지 증가한 결과를 보고하였다. Park 등(35)의 보고에서도 숙성온도와 기간에 비례하여 대추의 폴리페놀 함량이 증가 하는 결과를 나타내었다. 따라서 이러한 여러 연구 결과들 에 따르면 실질적으로 생리활성 물질 증가에는 고온의 환경 이 적합한 것으로 사료된다.

\section{십전대보환의 phenolic acids 및 flavonols 화합물 함량}

십전대보환의 phenolic acids와 flavonols 화합물을 분석 한 결과는 Table 5 과 같았다. Phenolic acids 화합물은 고온 숙성을 하지 않은 G-SDH의 경우 vanillic acid와 p-coumaric acid가 검출되지 않았고 HTA-SDH는 p-hydroxylbenzoic acid와 vanillic acid가 검출되지 않았다. 또한 gallic $\operatorname{acid}(53.54 \rightarrow 29.55 \mu \mathrm{g} / \mathrm{g})$, p-hydroxylbenzoic acid(1.38 $\mathrm{\mu g} / \mathrm{g}$ $\rightarrow \mathrm{ND})$, ferulic $\operatorname{acid}(49.88 \rightarrow 19.41 \mu \mathrm{g} / \mathrm{g})$, ventaric acid(58.78 $\rightarrow 17.58 \mu \mathrm{g} / \mathrm{g}$ ) 함량은 고온숙성 후 감소하는 것으로 나타났 고 protocatechuic acid(66.22 $\rightarrow 98.92 \mu \mathrm{g} / \mathrm{g})$, p-courmaric $\operatorname{acid}(\mathrm{ND} \rightarrow 2.33 \mu \mathrm{g} / \mathrm{g}), \mathrm{t}-\mathrm{cinnamic} \operatorname{acid}(19.14 \rightarrow 27.44 \mu \mathrm{g} / \mathrm{g})$ 함량은 고온 숙성 후 증가하였으며 특히 chlorogenic acid는 $23.09 \mu \mathrm{g} / \mathrm{g}$ 에서 $108.08 \mu \mathrm{g} / \mathrm{g}$ 으로 가장 크게 증가하였다. Flavan-3-ols 화합물은 공통적으로 vanillin이 검출되지 않았 고 $\mathrm{G}-\mathrm{SDH}$ 의 경우에는 naringin 및 naringenin이 검출되지 않았다. Epigallocatechin $(10.18 \rightarrow 18.82 \mu \mathrm{gg} / \mathrm{g})$, catechin $(63.27 \rightarrow 75.77 \mu \mathrm{g} / \mathrm{g})$, epicatechin(60.66 $\rightarrow 66.96 \mu \mathrm{g} / \mathrm{g})$, epigallocatechin gallate $(22.92 \rightarrow 39.0 \mu \mathrm{g} / \mathrm{g})$, catechin gallate $(39.41 \rightarrow 48.03 \mu \mathrm{gg} / \mathrm{g})$ 화합물들은 고온숙성 시 조금씩 증가하는 경향을 나타내었고 특히 rutin은 $3.26 \mu \mathrm{g} / \mathrm{g}$ 에서 $24.46 \mu \mathrm{g} / \mathrm{g}$ 으로 증가폭이 약 7.5 배로 가장 높게 증가하였다.
한편 quercetin $(90.9 \rightarrow 84.83 \mu \mathrm{g} / \mathrm{g})$ 과 formonoetin $(20.11 \rightarrow$ $10.51 \mu \mathrm{g} / \mathrm{g}$ )은 약간 감소하는 것으로 나타났으며 phenolic acid와 flavan-3-ols 총 함량은 각각 $303.31 \mu \mathrm{g} / \mathrm{g}$ 및 372.58 $\mu \mathrm{g} / \mathrm{g}$ 으로 고온숙성 시 증가하는 것으로 나타났다(Table 5).

Phenolic acids는 phenyl기에 hydroxyl기를 여러 개 갖는 방향환족 물질로서 다양한 식 - 약용 작물에 널리 분포되어 있는 물질로 보고되어있다(35). 고온숙성 과정 중 불용성 폴리페놀 화합물들이 세포막과 세포벽의 에스테르 결합이 파괴되어 수용성 폴리페놀 용출되거나, 고분자 폴리페놀 화합물들이 분해되어 저분자 페놀산 형태로 분해되어 용출 이 용이한 유리 형태로 전환된 것으로 추정되었다 (29,36-38).

Table 5. Comparison of phenolic acid and flavonol contents in Sibjeondaebohwan with balloon flower

\begin{tabular}{|c|c|c|}
\hline \multirow{2}{*}{ Contents $^{1)}(\mu \mathrm{g} / \mathrm{g})$} & \multicolumn{2}{|c|}{ Sibjeondaebohwan } \\
\hline & G-SDH' & HTA-SDH ${ }^{3)}$ \\
\hline \multicolumn{3}{|c|}{ Phenolic acids } \\
\hline Gallic acid & $53.54 \pm 2.68^{\mathrm{a}}$ & $29.55 \pm 1.48^{\mathrm{b}}$ \\
\hline Protocatechuic acid & $66.22 \pm 3.31^{\mathrm{b}}$ & $98.92 \pm 4.95^{\mathrm{a}}$ \\
\hline Chlorgenic acid & $23.09 \pm 1.15^{\mathrm{b}}$ & $108.08 \pm 5.40^{\mathrm{a}}$ \\
\hline p-Hydrobenzoic acid & $1.38 \pm 0.07^{\mathrm{a}}$ & $\mathrm{ND}^{4)}$ \\
\hline Vanillic acid & $\mathrm{ND}$ & ND \\
\hline p-Coumaric acid & $\mathrm{ND}$ & $2.33 \pm 0.12^{\mathrm{a}}$ \\
\hline Ferulic acid & $49.88 \pm 2.49^{\mathrm{a}}$ & $19.41 \pm 0.97^{\mathrm{b}}$ \\
\hline Vertaric acid & $58.78 \pm 2.94^{\mathrm{a}}$ & $17.58 \pm 0.88^{b}$ \\
\hline $\mathrm{t}$-Cinnamic acid & $19.14 \pm 0.96^{b}$ & $27.44 \pm 1.37^{\mathrm{a}}$ \\
\hline Total & $272.03 \pm 13.60^{b}$ & $303.31 \pm 15.17^{\mathrm{a}}$ \\
\hline \multicolumn{3}{|c|}{ Flavonols } \\
\hline Epigallocatechin & $10.18 \pm 0.51^{b}$ & $18.82 \pm 0.94^{\mathrm{a}}$ \\
\hline Catechin & $63.27 \pm 3.16^{b}$ & $75.77 \pm 3.79^{\mathrm{a}}$ \\
\hline Epicatechin & $60.66 \pm 3.03^{\mathrm{a}}$ & $66.96 \pm 3.35^{\mathrm{a}}$ \\
\hline Epigallocatechin gallate & $22.92 \pm 1.15^{\mathrm{b}}$ & $39.0 \pm 1.95^{\mathrm{a}}$ \\
\hline Vanilin & $\mathrm{ND}$ & $\mathrm{ND}$ \\
\hline Rutin & $3.26 \pm 0.16^{b}$ & $24.46 \pm 1.22^{\mathrm{a}}$ \\
\hline Catechin gallate & $39.41 \pm 1.97^{b}$ & $48.03 \pm 2.40^{\mathrm{a}}$ \\
\hline Quercetin & $90.9 \pm 4.55^{\mathrm{a}}$ & $84.83 \pm 4.24^{\mathrm{a}}$ \\
\hline Naringin & $\mathrm{ND}$ & $1.21 \pm 0.06^{\mathrm{a}}$ \\
\hline Naringenin & $\mathrm{ND}$ & $2.99 \pm 0.15^{\mathrm{a}}$ \\
\hline Formonoetin & $20.11 \pm 1.01^{\mathrm{a}}$ & $10.51 \pm 0.53^{b}$ \\
\hline Total & $310.71 \pm 15.54^{b}$ & $372.58 \pm 18.63^{\mathrm{a}}$ \\
\hline
\end{tabular}

${ }^{1)}$ All values are presented as the mean \pm SD of triplicate determination. All values within a column with different superscript letters are significantly from each other at $\mathrm{p}<0.05$ by Duncan's multiple range test.

${ }^{2)}$ G-SDH: General Sibjeondaebohwan.

${ }^{3}$ HTA-SDH: High temperature aging Sibjeondaebohwan.

${ }^{4} \mathrm{ND}$ : not detected. 


\section{십전대보환의 라디칼 소거활성}

G-SDH 및 HTA-SDH의 DPPH, ABTS, 및 hydroxyl 라디 칼 소거활성을 비교한 결과는 Table 6에 나타내었다. DPPH 라디칼 소거활성은 십전대보환 추출물의 농도가 $1 \mathrm{mg} / \mathrm{mL}$ 일 때 68.14\%(G-SDH) 및 85.65\%(HTA-SDH)로 가장 높게 나타났다. $0.5-0.25 \mathrm{mg} / \mathrm{mL}$ 농도에서는 G-SDH가 31.25 및 $12.34 \%$ 를 나타내었고 HTA-SDH에서는 46.12 및 $20.44 \%$ 로 $\mathrm{G}-\mathrm{SDH}$ 보다 좀 더 우수한 DPPH 라디칼 소거활성을 나타내 었다. ABTS 라디칼 소거활성 역시 처리 농도가 클수록 증가하는 경향을 나타내었다. $0.25 \mathrm{mg} / \mathrm{mL}$ 처리 시 G-SDH 는 $24.34 \%$ 를 나타내었고 HTA-SDH는 $33.86 \%$ 를 나타내었 다. $0.5 \mathrm{mg} / \mathrm{mL}$ 처리 시에는 $43.97 \%(\mathrm{G}-\mathrm{SDH})$ 와 $68.38 \%$ (HTA-SDH)를 나타내었고 $1.0 \mathrm{mg} / \mathrm{mL}$ 처리 시에는 $70.86 \%$ (G-SDH) 및 89.93\%(HTA-SDH)로 ABTS 라디칼 소거활성 이 좀 더 증가하였다. Hydroxyl 라디칼 소거활성은 ABTS 및 $\mathrm{DPPH}$ 보다는 라디칼 소거활성이 낮게 측정되었다. 1.0 $\mathrm{mg} / \mathrm{mL}$ 농도에서 $\mathrm{G}-\mathrm{SDH}$ 는 $48.04 \%$ 의 소거활성을 보였으며 HTA-SDH는 63.69\%를 나타내었다(Table 6).

일반적으로 라디칼 소거활성은 폴리페놀 화합물들의 함 량과 큰 상관관계가 있는 것으로 보고되어있다(36). 따라서 본 연구에서의 라디칼 소거활성 증가 현상은 고온숙성 처리 에 따른 유리형태의 폴리페놀 화합물들의 함량 증가에 기인 한 것으로 추측되었다. 이러한 결과는 Woo 등(18)의 감초 추출물에서 IC50 값으로 라디칼 소거활성을 측정한 결과 $0.57 \rightarrow 0.32 \mathrm{~g} / \mathrm{L}$ 로 낮아져 본 연구와도 유사한 경향을 나타 내었으며 Yang 등(20)의 인삼에서도 IC50 값으로 나타냈을 시 $17.68 \rightarrow 0.22 \mathrm{mg} / \mathrm{g}$ 로 열처리 시 라디칼 소거활성이 크게 증가함을 보고하였다. 따라서 본 연구에서는 십전대보환 열처리 시 유리형의 폴리페놀 화합물들이 많이 용출되며 이로 인해 항산화 효과가 증가된 것으로 추정되었다.

\section{십전대보환의 소화효소 저해활성}

G-SDH 및 HTA-SDH의 a-glucosidase, a-amylase 및 pancreatic lipase 저해활성을 측정한 결과는 Table 6에 나타 내었다. a-Glucosidase 저해활성은 각각의 추출물 농도가 $1 \mathrm{mg} / \mathrm{mL}$ 일 때 G-SDH는 $22.05 \%$ 의 낮은 활성을 나타낸 반면 HTA-SDH는 $61.06 \%$ 의 우수한 저해활성을 나타내었 다. 또한 추출물의 처리 농도에 비례하여 농도 의존적인 결과를 나타내었다(Table 6). a-Amylase 저해활성은 a -glucosidase보다는 활성이 약간 낮은 경향을 나타내었다. $0.25 \mathrm{mg} / \mathrm{mL}$ 농도에서는 $\mathrm{G}-\mathrm{SDH}$ 의 경우 $0.12 \%$ 로 저해활성 을 나타내지 않았으며 HTA-SDH 역시 $4.28 \%$ 를 나타내었 다. 농도가 증가할수록 저해활성 역시 조금씩 증가하는 경 향을 나타내었고 $1 \mathrm{mg} / \mathrm{mL}$ 농도에서는 G-SDH가 $15.25 \%$ 를 나타내었고 HTA-SDH는 $34.21 \%$ 의 a-amylase 저해활성을 나타내었다(Table 6). Pancreatic lipase 저해활성 역시 a -glucosidase 및 a-amylase와 같은 결과로 농도가 클수록 저해활성이 증가하는 경향을 나타내었다. $0.25 \mathrm{mg} / \mathrm{mL}$ 농도 에서는 각각 $3.36 \%(\mathrm{G}-\mathrm{SDH})$ 및 $9.64 \%(\mathrm{HTA}-\mathrm{SDH})$ 로 저해활 성이 크게 나타나진 않았으나 $0.5 \mathrm{mg} / \mathrm{mL}$ 농도에서는 약간 증가하여 $10.57 \%(\mathrm{G}-\mathrm{SDH})$ 와 $28.96 \%(\mathrm{HTA}-\mathrm{SDH})$ 를 나타내 었으며 $1 \mathrm{mg} / \mathrm{mL}$ 농도에서는 더욱 증가하여 $48.14 \%$ $(\mathrm{G}-\mathrm{SDH})$ 및 64.89\%(HTA-SDH)를 나타내어 고온숙성 처리 시 소화효소 저해활성이 크게 증가하는 것으로 나타났다 (Table 6).

a-Glucosidase 저해활성은 소장에서 포도당의 흡수를 지 연 및 차단시켜 식후 급격한 혈당상승을 억제할 수 있다 (39). 특히 고온숙성의 대표적 식품인 홍삼의 경우 Kim 등 (40)의 연구에 따르면 당뇨 유발쥐에게 팽화홍삼을 투여한 결과 대조군 $(477.40 \mathrm{mg} / \mathrm{dL})$ 에 비해 혈 당농도가 380.89

Table 6. Comparison of antioxidant activity and digestive enzyme inhibition activity in Sibjeondaebohwan with balloon flower

\begin{tabular}{|c|c|c|c|c|c|c|}
\hline & \multicolumn{3}{|c|}{ G-SDH ${ }^{2}$} & \multicolumn{3}{|c|}{ HTA-SDH ${ }^{3)}$} \\
\hline & \multicolumn{6}{|c|}{ Treatment of concentrations (mg/mL) } \\
\hline & 1.0 & 0.5 & 0.25 & 1.0 & 0.5 & 0.25 \\
\hline \multicolumn{7}{|c|}{ Antioxidant activity } \\
\hline DPPH & $68.64 \pm 3.43^{\mathrm{b}}$ & $31.25 \pm 1.56^{\mathrm{d}}$ & $12.34 \pm 0.62^{\mathrm{f}}$ & $85.65 \pm 4.28^{\mathrm{a}}$ & $46.12 \pm 2.31^{c}$ & $20.44 \pm 1.02^{\mathrm{e}}$ \\
\hline ABTS & $70.86 \pm 3.54^{\mathrm{b}}$ & $43.97 \pm 2.20^{c}$ & $24.34 \pm 1.22^{\mathrm{e}}$ & $89.93 \pm 4.50^{\mathrm{a}}$ & $68.38 \pm 3.42^{\mathrm{b}}$ & $33.86 \pm 1.69^{d}$ \\
\hline Hydroxyl & $48.04 \pm 2.40^{\mathrm{b}}$ & $21.35 \pm 1.07^{\mathrm{d}}$ & $8.99 \pm 0.45^{\mathrm{f}}$ & $63.69 \pm 3.18^{\mathrm{a}}$ & $33.45 \pm 1.67^{\mathrm{c}}$ & $14.68 \pm 0.73^{\mathrm{e}}$ \\
\hline \multicolumn{7}{|c|}{ Digestive enzyme inhibition activity } \\
\hline a-Glucosidase & $22.05 \pm 1.10^{\mathrm{b}}$ & $10.57 \pm 0.53^{\mathrm{d}}$ & $3.36 \pm 0.17^{e}$ & $61.06 \pm 3.05^{\mathrm{a}}$ & $28.96 \pm 1.45^{\mathrm{c}}$ & $9.64 \pm 0.48^{\mathrm{d}}$ \\
\hline a-Amylase & $15.25 \pm 0.76^{b}$ & $8.89 \pm 0.44^{c}$ & $0.12 \pm 0.01^{\mathrm{e}}$ & $34.21 \pm 1.71^{\mathrm{a}}$ & $17.23 \pm 0.86^{\mathrm{b}}$ & $4.28 \pm 0.21^{\mathrm{d}}$ \\
\hline Pancreatic Lipase & $48.14 \pm 2.41^{\mathrm{b}}$ & $10.57 \pm 0.53^{\mathrm{d}}$ & $3.36 \pm 0.17^{\mathrm{e}}$ & $64.89 \pm 3.24^{\mathrm{a}}$ & $28.96 \pm 1.45^{\mathrm{c}}$ & $9.64 \pm 0.48^{\mathrm{d}}$ \\
\hline
\end{tabular}

\footnotetext{
${ }^{1)}$ All values are presented as the mean \pm SD of triplicate determination. All values within a column with different superscript letters are significantly from each other at $p<0.05$ by Duncan's multiple range test.

${ }^{2)}$ G-SDH: General Sibjeondaebohwan.

${ }^{3)}$ HTA-SDH: High temperature aging Sibjeondaebohwan.
} 
$\mathrm{mg} / \mathrm{dL}$ 로 유의적으로 감소함을 보고하였다. Kim 등(41)은 홍삼이 고혈 당 유발 시 혈당강하작용이 있음을 보고하였 다. 본 연구결과 역시 in vitro 상에서의 항당뇨 및 항비만 효능이 있으므로 향후에는 in vivo 연구가 필요할 것으로 사료된다. 또한 보통 폴리페놀 화합물을 함유하는 식물 추 출물은 지방세포의 분해를 억제하고 지질 축적을 감소시킨 다고 학계에 알려져 있어(42) 본 연구의 고온숙성 중 생성된 phenolic acids 및 flavonols 화합물 함량에 기인하여 항당뇨 및 항비만 효능이 있는 것으로 추정되었다.

\section{십전대보환의 RAW264.7 대식세포주에서 면역 활성}

RAW264.7 세포에서 십전대보환 추출물에 의한 산화질 소(nitric oxide, NO) 생성을 확인한 결과 Fig. 2 및 Fig. 3과 같았다. 무처리군에서는 NO가 생성되지 않았으나 LPS를 처리한 대조군에서는 $70 \mu \mathrm{M}$ 정도의 $\mathrm{NO}$ 가 생성되었고, G-SDH는 무처리군과 비슷한 수준 있었고 고온숙성 십전대 보환(HTA-GDH)에서는 No 생성량이 약간 증가하였다(Fig. 2). RAW264.7 대식세포주에서 십전대보환 추출물에 대한 iNOS, COX-2, TNF-a 단백질 발현을 측정한 결과 LPS 처리 군에 비해 십전대보환(G-SDH 및 $\mathrm{HTA}-\mathrm{SDH})$ 추출물은 iNOS, COX-2 및 TNF-a 단백질 발현을 유발하는 결과를 나타내었으며, 특히 HTA-SDH 추출물의 $5 \mathrm{mg} / \mathrm{mL}$ 처리 시 현저한 단백질 발현 증가가 관찰되었다. 따라서 십전대보 환은 대식세포의 사이토카인 발현을 유도하여 면역기능을 조절하는 효능이 있는 것으로 판단되었다(Fig. 3).

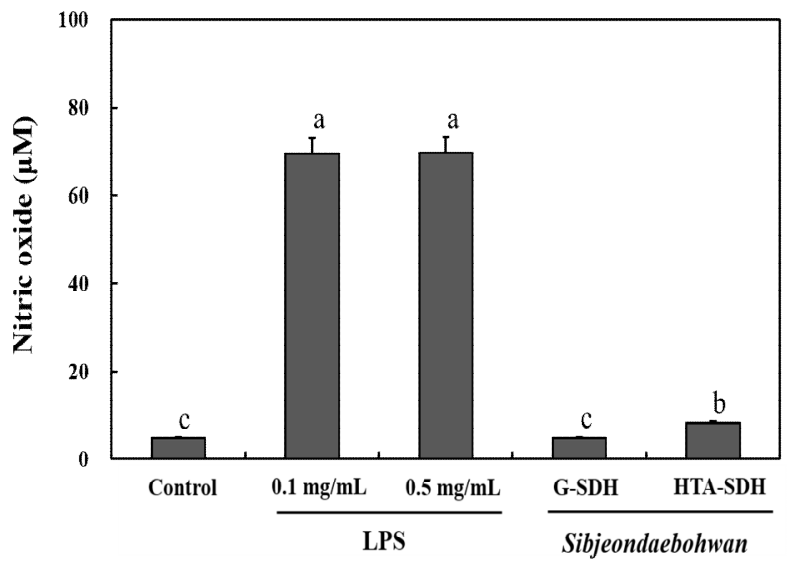

Fig. 2. Inhibitory effect of NO production on RAW264.7 macrophage cells. LPS, lipopolysaccharide $(0.1$ and $0.5 \mathrm{mg} / \mathrm{mL}$; G-SDH, general Sibjeondaebohwan $(1 \mathrm{mg} / \mathrm{mL})$; and HTA-SDH, high temperature aging Sibjeondaebohwan $(1 \mathrm{mg} / \mathrm{mL})$.

All values are means of determination in three independent experiments. All values within a column with different superscript letters are significantly different from each other at $\mathrm{p}<0.05$ by Duncan's multiple range test.

면역은 선천 면역(비특이적 면역)과 적응 면역(체액성과 세포매개성 면역)으로 구분할 수 있습니다. 본 연구에서는 선천 면역인 비특이적 면역 활성을 진행하였고 면역 인자로
No, iNOS, Cox-2, TNF- $a$ 를 측정하였다. 대식세포는 살아있 는 생체 내 면역을 극대화시키는 중요 매개체로 활성화된 대식세포에서 $\mathrm{NO}$ 을 생산하고 이러한 $\mathrm{NO}$ 는 비특이적 숙주 방어 기작인 대식작용과 세균 및 암세포의 증식을 억제하는 활성을 보인다(31,41). 본 연구의 도라지 함유 십전대보환 에는 도라지 $(9 \%)$ 외에도 백복령, 백출, 숙지황, 백작약, 감 초, 황기, 육계, 당귀, 천궁 및 대추 등이 함유되어 있다. 한편 Kang 등(32)은 도라지 함유 활맥단 한방 추출액에는 도라지 외에도 다양한 면역 활성조절인자들로 구성되어 있는 한약재가 포함되었기 때문에 대식세포에서의 면역 조절활성에 관련된 유전자들이 발현을 증가시키는 것으로 보고하였다. $\mathrm{Yu}$ 등(43)은 생약 12종 중 단백질과 다당체가 함유된 감초, 건지황, 당귀, 도라지 및 목천료의 추출물은 RAW264.7 세포에 처리하였을 때 면역 활성의 지표가 되는 $\mathrm{NO}$, cytokine(TNF-a)의 생성이 추출물을 처리하지 않은 대 조군에 비해 증가하는 것으로 보고하였으며, 이는 인체의 비특이적 면역반응을 증가시킴으로써 항원을 공격, 제거하 는 등의 작용을 통해 자연 면역반응에 있어 중요한 역할을 할 수 있을 것으로 추정하였다.

고온숙성법을 통하여 도라지 함유 십전대보환을 제조한 결과 영양성분은 고온숙성에 따라 감소하였으나, 총 폴리 페놀, 총 플라보노이드, 갈변물질, 총 phenolic acids 및 총 flavonols 함량이 높았고, 이에 따라 $\mathrm{DPPH}, \mathrm{ABTS}$ 와 hydroxyl 라디칼 소거활성 및 a-glucosidase, a-amylase 및 plancreatic lipase 저해활성은 역시 높았다. 특히 고온숙성에 의해 제조된 십전대보환은 대식세포주에서 면역 활성이 일반십전대보환보다 우수하였고 식품위해미생물 역시 검 출되지 않아 안전성과 기능성이 십전대보환 제조가 가능할 것으로 판단되었다.
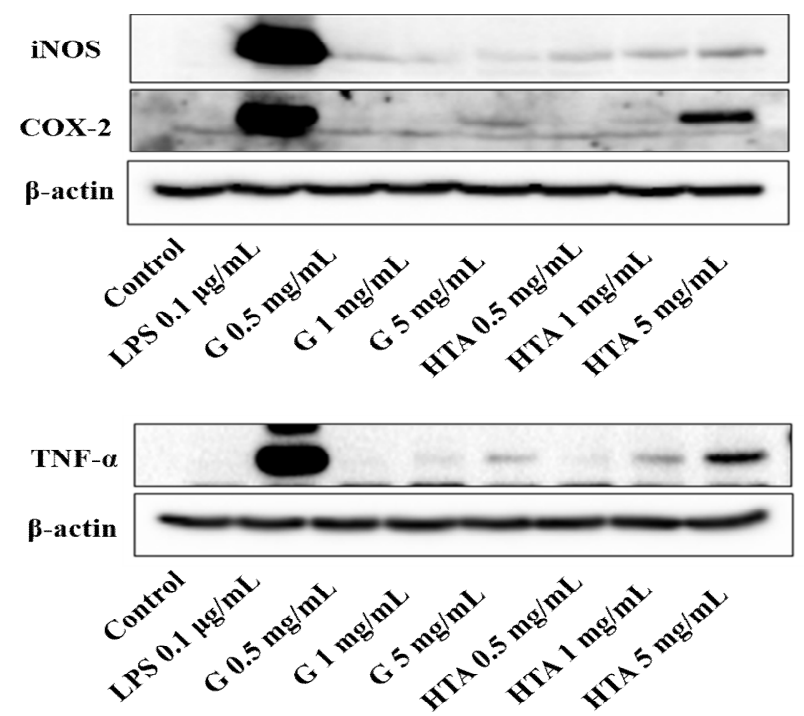

Fig. 3. Determination of iNOS, COX-2, and TNF-a protein expression levels in RAW264.7 macrophage cells.

LPS, lipopolysaccharide $(0.1 \mathrm{\mu g} / \mathrm{mL})$; G-SDH, general Sibjeondaebohwan $(0.5,1$, and $5 \mathrm{mg} / \mathrm{mL})$; and HTA-SDH, high temperature aging Sibjeondaebohwan (0.5, 1, and $5 \mathrm{mg} / \mathrm{mL}$ ) 


\section{요 약}

본 연구에서는 도라지를 비롯한 10 가지 약재를 혼합하여 십전대보환을 제조하였다. 일반 십전대보환(G-SDH)과 고 온숙성 십전대보환(HTA-SDH)의 영양성분(5대 영양소, 지 방산, 및 유리아미노산), 생리활성 물질(phenolic acid 및 flavonols), 라디칼 소거활성(DPPH, ABTS 및 hydroxyl), 소 화효소 저해활성(a-glucosidase, a-amylase 및 lipase) 및 면 역기능을 비교 · 분석하였다. 조회분, 조지방, 조단백질, 탄 수화물, 총 지방산 및 총 유리아미노산 함량은 G-SDH가 HTA-SDH보다 높았다. 주요 지방산의 경우 G-SDH는 oleic acid, HTA-SDH는 linoleic acid가 있었다. G-SDH의 주요 아미노산은 aspartic acid와 glutamic acid, HTA-SDH는 aspartic acid가 있었다. HTA-SDH가 G-SDH보다 총 폴리페 놀, 총 플라보노이드, 갈변물질, 총 phenolic acids 및 총 flavonols 함량이 높았다. 특히, phenolic acids는 $272.03 \mathrm{\mu g} / \mathrm{g}$ 에서 $303.31 \mu \mathrm{g} / \mathrm{g}$ flavonols은 $310.71 \mu \mathrm{g} / \mathrm{g}$ 에서 $372.58 \mu \mathrm{g} / \mathrm{g}$ 로 증가하였다. $1.0 \mathrm{mg} / \mathrm{mL}$ 처리 시, $\mathrm{DPPH}, \mathrm{ABTS}$ 와 hydroxyl 라디칼 소거활성 및 a-glucosidase, a-amylase 및 plancreatic lipase 저해활성은 각각 $85.65 \%, 89.93 \%, 63.69 \%, 61.06 \%$, $34.21 \%, 64.89 \%$ 로 HTA-SDH가 G-SDH보다 높았다. 한편 고온숙성에 의해 제조된 십전대보환(HTA-SDH)는 면역기 능을 조절하는 효능이 있는 것으로 판단되었다.

\section{감사의 글}

본 연구는 농림축산식품부 고부가가치식품개발사업(과 제번호: 116009-3) 및 농림축산식품부 농생명산업기술개 발사업(과제번호: 314021-03)에 의해 이루어진 결과입니 다.

\section{References}

1. Lee SH, Song EM, Jang GY, Li M, Kim MY, Park HJ, Kang TS, Jeong HS (2013) Physicochemical characteristics and antioxidant Activities of Doragi (Platycodon grandiflorum) at different aging temperatures and for various durations. J Korean Soc Food Sci Nutr, 42, 1405-1411

2. Akiyama T, Tanaka O, Shibata S (1972) Chemical studies on the oriental plant drugs. XXX. Sapogenins of the roots of Platycodon grandiflorum A. DE Candolle. (1) Isolation of the sapogenins and the stereochemistry of polygalacic acid. Chem Pharm Bull, 20, 1945-1951

3. Chang YJ, Kim E, Choi YS, Jeon KH, Kim YB (2015)
Development process for decreasing bitterness of Doraji (Platycodon grandiflorum). J Korean Soc Food Sci Nutr, 44, 1550-1557

4. Hwang CR, Oh SH, Kim HY, Lee SH, Hwang IG, Shin YS, Lee JS, Jeong HS (2011) Chemical composition and antioxidant activity of Deoduk (Codonopsis lanceolata) and Doraji (Platycodon grandiflorum) according to temperature. J Korean Soc Food Sci Nutr, 40, 798-803

5. Seo JK, Chung YC, Chun SS, Lee YY, Lee SJ, Shon MY, Sung NJ (2004) Effect of physiologically active compounds isolated from Platycodon grandiflorum on streptozotocin induced diabetic rats. J Korean Soc Food Sci Nutr, 33, 981-986

6. Kim YS, Kim JS, Choi SU, Kim JS, Lee HS, Roh SH, Jeong YC, Kim YK, Ryu SY (2005) Isolation of a new saponin and cytotoxic effect of saponins from the root of Platycodon grandiflorum on human tumor cell lines. Planta Med, 71, 566-568

7. Hwang SY, Choi HM, Lim SY (2013) Total phenolics of dried Platycodon grandiflorum and its effect on growth of human cancer cell lines. Korean J Food Sci Technol, $45,84-89$

8. Ahn KS, Noh EJ, Zhao HL, Jung SH, Kang SS, Kim YS (2005) Inhibition of inducible nitric oxide synthase and cyclooxygenase $\Pi$ by Platycodon grandiflorum saponins via suppression of nuclear factor- $\mathrm{kB}$ activation in RAW264.7 cells. Life Sci, 76, 2315-2328

9. Lee H, Kang R, Kim YS, Chung SI, Yoon Y (2010) Platycodin D inhibits adipogenesis of 3T3-L1 cells by modulating Kruppel-like factor 2 and peroxisome proliferator-activated receptor gamma. Phytother Res, 24, 161-167

10. Kim CH, Jung BY, Jung SK, Lee CH, Lee HS, Kim BH, Kim SK (2010) Evaluation of antioxidant activity of Platycodon grandiflorum. J Environ Toxicol, 25, 85-94

11. Jang JR, Hwang SY, Lim SY (2011) Inhibitory effect of extracts of Platycodon grandiflorum (the ballon flower) on oxidation and nitric oxide production. Korean J Food Preserv, 18, 65-71

12. Lee KJ, You HJ, Park SJ, Kim YS, Chung YC, Jeong TC, Jeong HG (2001) Hepatoprotective effects of Platycodon grandiflorum on acetaminophen induced liver damage in mice. Cancer Lett, 174, 73-81

13. Jeong SI, Yu HH (2013) Quality characteristics of Sikhe prepared with the roots powder of Doraji (Platycodon grandiflorum A. DE. Candolle). J Korean Soc Food Sci Nutr, 42, 759-765 
14. Lee ST, Kim MB, Kim DK, Ryu JS, Lee HJ, Hae JS (1998) Production of curd yogurt from Platycodon grandiflorum (Jacq) A. DC. Korean J Medicinal Crop Sci, 6, 265-270

15. Lee GD, Joo GJ, Kwon JH (2000) Optimization for roast flavour formation of Platycodon grandiflorum tea. J Korean Soc Food Sci Nutr, 29, 752-757

16. Jeong EJ, Kim KP, Bang BH (2013) Quality characteristics of cookies containing Platycodon grandiflorum powder. Korean J Food Nutr, 26, 759-765

17. Yang HJ, Weon JB, Ma JY, Ma CJ (2011) The study on compounds of the fermented Sipjundaebotang and its neuroprotective activity. YakHTAk Hoeji, 55, 121-126

18. Woo KS, Jang KI, Kim KY, Lee HB, Jeong HS (2006) Antioxidative activity of heat treated licorice (Glycyrrhiza uralensis Fisch) extracts. Korean J Food Sci Technol, 38, 355-360

19. Song DS, Woo KS, Seong NS, Kim KY, Jeong HS, Lee HB (2007) Changes in quality of Rehmanniae radix preparata with heating conditions. J Korean Soc Food Sci Nutr, 36, 773-778

20. Yang SJ, Woo KS, Yoo JS, Kang TS, Noh YH, Lee JS, Jeong HS (2006) Change of Korean ginseng components with high temperature and pressure treatment. Korean J Food Sci Technol, 38, 521-525

21. Lee SJ, Shin SR, Yoon KY (2013) Physicochemical properties of black Doraji (Platycodon grandiflorum). Korean J Food Sci Technol, 45, 422-427

22.Yang MC, Jeong SW, Ma JY (2011) Analysis of constituents in Sipjundaebotangs fermented by lactic acid bacteria. Korean J Microbiol Biotechnol, 39, 350-356.

23. http://www.foodsafetykorea.go.kr/foodcode/index.jsp

24. Kang SK (2007) Changes in proximate composition, free amino acid, free sugar and vitamin of Curcuma longa L. and Curcuma atomatica salib according to picking time. Korean J Food Preserv, 14, 624-632

25. Folin O, Denis W (1912) On phosphotungsticphosphomolybdic compounds as color reagents. J Biol Chem, 12, 239-243

26. Lee HY, Shin YM, Hwang CE, Lee BW, Kim HT, Ko JM, Baek IY, An MJ, Choi JS, Seo WT, Cho KM (2014) Production of soybean meat using korean whole soybean and it's quality characteristics and antioxidant activity. J Agric Life Sci, 48, 139-156

27.Ahn MJ, Yuk HJ, Lee HY, Hwang CE, Jeong YS, Hong SY, Kwon OK, Kang SS, Kim HR, Park DS, Cho KM (2015) Effect of the enhanced biological activities and reduced bitter taste of bitter Melon (Momordica charantia
L.) by roasting. J Agric Life Sci, 49, 107-119

28. Cho KM, Joo OS (2014) Quality and antioxidant characteristics of Elaegnus multiflora wine through the thermal processing of juice. Korean J Food Preserv, 21, 206-214

29. Cho KM, Hwang CE, Joo OS (2017) Change of physicochemical properties, phytochemical contents and biological activities during the vinegar fermentation of Elaegnus multiflora fruit. Korean J Food Preserv, 24, $125-133$

30. Park JH, Baek MR, Lee BH, Yon GH, Ryu SY, Kim YS, Park SU, Hong KS (2009) a-Glucosidase and a -amylase inhibitory activity of compounds from roots extract of Pueraria thunbergiana. Korean J Medicinal Crop Sci, 17, 357-362

31. Kwon OJ, Lee HY, Kim TH, Kim SG (2014) Antioxidant and pancreatic lipase inhibitory activities of Anemarrhena asphodeloides. Korean J Food Preserv, 21, 421-426

32. Kang SA, Chun SS, Kang SK, Chung YC, Cheon EW, Cho SU, Jung KH, Ahn SC, Yu HS (2014) Gene expression analysis of immune cell activation markers in extracts of Platycodon grandiflorum containing medicinal herbs. J Life Sci, 24, 567-572

33. Van Boekel MA (2006) Formation of flavour compounds in the maillard reaction. Biotechnol Adv, 24, 230-233

34. Kim AK, Lee CY, Hwang KH, Lee YJ, Kim SJ, Lee YJ, Lee HK, Lee SR, Kim IY, Lee JM, Yu IS, Jung K (2016) Quality variation of Sibjeondaebotang according to long-term storage. Kor J Pharmacogn, 47, 374-380.

35. Park JH, Lee SH, Kim HY, Jang GY, Hwang IG, Woo KS, Kwon OS, Lee JS, Jeong HS (2012) Changes in chemical components and antioxidant activity of dried jujube with different aging temperatures and durations. J Korean Soc Food Sci Nutr, 41, 591-597

36. Choi JS, Kim HY, Seo WT, Lee JH, Cho KM (2012) Roasting enhances antioxidant effect of bitter melon (Momordica charantia L.) increasing in flavan-3-ol and phenolic acid contents. Food Sci Biotechnol, 21, 19-26

37. Sahin H, Topuz A, Pischetsrieder M, Ozdemir F (2009) Effect of roasting process on phenolic, antioxidant, and browning properties of carob powder. Eur Food Res Technol, 230, 155-161

38. Chandrasekara N, Shahidi F (2011) Antioxidative potential of cashew phenolics in food and biological model systems as affected by roasting. Food Chem, 129, 1388-1396 
39.Hong JH, Kim HJ, Choi YH, Lee IS (2008) Physiological activities of dried persimmon, fresh persimmon and persimmon leaves. J Korean Soc Food Sci Nutr, 37, 957-964

40.Kim SH, Kang JS, Lee SJ, Chung YJ (2008) Antidiabetic effect of Korean red ginseng by puffing process in streptozotocin-induced diabetic rats. J Korean Soc Food Sci Nutr, 37, 701-707

41. Kim HS, Seong YH, Yang JW, Jeon BS, Park UY, Park WK, Oh KW, Choi KJ (1997) Hypoglycemic effects of extract mixture of red ginseng and steamed Rehmaniae radix on streptozotocin-induced diabetic rats. Korea J Ginseng Sci, 21, 169-173
42.Park YJ, Nam JY, Yoon DE, Kwon OC, Kim HI, Yoo YB, Kong WS, Lee CS (2013) Comparison of anti-inflammatory, antioxidant and anti-allergic effects of Ganoderma species mycelial extracts. J Mushroom Sci Prod, 11, 111-115

43.Yu AR, Park HY, Choi IW, Park YK, Hong HD, Choi HD (2012) Immune enhancing effect of medicinal herb extracts on a RAW 264.7 macrophage cell line. J Korean Soc Food Sci Nutr, 41, 1521-1527 